\title{
A multidisciplinary approach to urban fabrics analysis. The historical centre of Valencia
}

\author{
Marco Maretto ${ }^{1}$, Vicente Mas Llorens ${ }^{2}$, Eva Alvarez ${ }^{2}$, Barbara Gherri ${ }^{1}$, \\ Carlos Gomez ${ }^{2}$, Maria Rosaria Guarini ${ }^{3}$, Anthea Chiovitti ${ }^{3}$, Gianluca \\ $\mathbf{E m m i}^{3}$ \\ ${ }^{1}$ Department of Engineering and Architecture. University of Parma. Parma, Italy \\ ${ }^{2}$ Escuela Técnica Superior de Arquitectura. Universitat Politècnica de València. Valencia, Spain \\ ${ }^{3}$ Department of Architecture and Design, School in Architecture and Construction, University of \\ Rome-La Sapienza. Roma, Italy \\ E-mail:marco.maretto@unipr.it,vmas@pra.upv.es, ealvarez@pra.upv.es, barbara.gherri@unipr. \\ it,mariarosaria.guarini@uniroma1.it, anthea.chiovitti@uniroma1.it, gianluca.emmi@libero.it
}

\begin{abstract}
The themes of reduce, recycle, reuse are at the heart of the challenges that the global society of the XXI century is facing. At the same time, more than two-thirds of the world population lives in cities nominating the latters to play a central role in the near future. For this reason, the search for a methodology for the redevelopment of the historical urban fabrics appears today extremely interesting. Complexity, richness and stratification of the latters make them definitely the most convincing test to set a scientific strategy for the project of urban transformations. But stratification means complexity and complex are the phenomena that characterize the XXI century society. The only convincing way then for the analysis of these phenomena is that of the multi-disciplinarity. The proposed methodology is structured, thus, around a number of disciplines (Urban Morphology, Sustainability, Urban Regulation, Economic Evaluation and Urban Design) on which to set the reading of the urban fabric with special attention to the so called "urban voids" namely all those situations in which the tissue is interrupted due to slumping and demolitions. This aspect is very important because if, on the one hand, it is in these areas where key tissue analysis problems can be seen, on the other hand, it is always from these areas that the main urban, social and economical transformation opportunities can take boot. A Due Diligence of the "urban voids" organised in datasheets/base (for each area) concludes the analysis. The different disciplinary fields work then in a complementary way within a single methodological approach laying the scientific basis for the interventions of urban regeneration within the historic fabric of Valencia.
\end{abstract}

Keywords: urban morphology, urban fabric, multidisciplinary, methodology, Valencia.

\section{Introduction}

Urban transformation, urban regeneration, urban sustainability are just some of the key words identifying city's trend in this early XXI century. Particularly sensitive is their application to the compact and historical city. Complexity, richness and stratification of its fabrics actually make them definitely the most convincing test to set a scientific strategy for the project of urban transformations. But urban phenomena are extremely dynamic and do not lend themselves to a univocal method. For this reason a multidisciplinary approach has been put at the base of current research structuring a methodology around a number of disciplines 
(Urban Morphology, Sustainability, Urban Regulation, Economic Evaluation and Urban Design) on which to set the reading of the urban fabric with special attention to the so called "urban voids" namely all those situations in which the tissue is interrupted due to slumping and demolitions. This aspect is very important because if, on the one hand, it is in these areas where key tissue analysis problems can be seen, on the other hand, it is always from these areas that the main urban, social and economical transformation opportunities can take boot. This paper represents a first step in this direction. In particular a methodology for a Due Diligence of the "urban voids" will be proposed. It is organised in datasheets in which different disciplinary fields work in a complementary way laying the scientific basis for the interventions of urban regeneration within the historic fabric of Valencia.

\section{Methodology}

From a methodological point of view, the first choice was to contain the field of inquiry within the Ciudad Vella. An area extending for 142 ha inside the former Christian wall built up by Pedro IV El Ceremonioso in 1356. The historic city, in fact, has the double circumstance of being, on the one hand, a "contemporary city" in all respects, and therefore a valid ground for verification for all urban transformation processes, on the other hand, to be characterized by a strong stratification. This latter aspect is particularly relevant. Stratification means the wealth of "contextual factors" for which the only way forward, as always, is that of the recovery, reuse, re-functioning, in-fill and so on, all concepts that arise at the base of any reasoning about the future of cities that want to have, today, scientific credibility. The historic city seems therefore to be the most convincing test bench for setting up a scientific strategy for urban transformation projects. The second choice, as mentioned, was that of multi-disciplinarity. In particular, some basic disciplines have been identified around which to build an organic and effective methodological format. The areas in question are those of Urban Morphology, Environmental
Sustainability, Urban Planning, Economic Evaluation and, of course, Urban Design as a necessary final synthesis tool. Through an analysis and cataloguing of solares, it was attempted to reconnect them with the built fabric by adopting a methodology set from the beginning on a multidisciplinary basis in order to face ex-ante, in an organic and effective way, the complex issues of the contemporary city without having to send third parties, or ex-post audits, actions that would be out of touch with the methodological context: a methodology capable of developing, therefore, a multidisciplinary strategic format on which to base urban retraining interventions within historic centers. In particular a methodology for a Due Diligence of the "urban voids" has been proposed. It is organised in datasheets in which different disciplinary fields work in a complementary way laying the scientific basis for the interventions of urban regeneration within the historic fabric of Valencia.

\section{Types of Solares}

We have seen how the formation of solares, albeit of various nature, results from the demolition or collapse of an existing building. Depending on the size and location of the demolished building, some types of voids can be identified.

In particular, we can outline six typed urban voids typologies, as follows:

-Enclosed. Interstitial free lot, with one front opened on the road

-Through. Interstitial free lot, with two fronts opened on the road

-Head. ree lot at the end of a building line (with one or two opened front roads)

-Angular. Corner free lot, with three fronts opened on the road

-Protruding. Interstitial free lot, with protruding fronts on a road

-Isolated. Isolated free lotto, with four fronts opened on the road.

In addition, there are a number of Aggregate voids that cross several blocks in which the above mentioned categories add to the presence of unstructured open spaces (i.e. never built or otherwise no longer building) that, by size and 
shape, acquire autonomy and a clearly legible identity within the urban fabric. As we shall see later, in fact, the size of solares, is often the result of mergers of several land parcels. It is then easy to assimilate the typological division of the individual lots into their groupings, treating them from now as a single project area composed of different parts. Although it is evident that each Solar has to be analyzed and studied individually, their subdivision into types appears to be extremely useful to provide the basis for a global solution of the phenomenon, the dimensions of which now escape the logic of the "case by case" requiring a common multidisciplinary methodology. An approach that, because of the large and complex nature of the phenomenon can become useful for an intervention strategy on degraded historical fabrics.

\section{Due Diligence Solares}

After a first phase of collection and reconnaissance of the data needed to develop the research, and after a detailed cataloguing of all solares belonging within the perimeter of Christian walls, it was decided to select number case studies. The decision on which examples to propose, among the more than a hundred voids found in the historic center, is based on typological and dimensional reasons. Four representative cases of the various types of solares have been then attempted.

Solar A

Location: C. Boatella, C. Valeriola, C. Eixarchs Type: Head

Total surface area: $\quad 826.94 \mathrm{~m} 2$

Property: Private

Parcels number: $\quad 7$

Sub-parcels number: 16

Current State: Abandon

Urban Qualification: (US) Urban Soil

Solar B

Location: C. Corregeria, C. Tapineria

Type: Angular

Total surface area: $\quad 160.38 \mathrm{~m} 2$

Property: Private

Parcels number: $\quad 4$
Sub-parcels number:

Current State:

6

Urban Qualification:

Abandon

(US) Urban Soil

Solar C

Location:

Type:

Total surface area:

Property:

Parcels number:

Sub-parcels number:

Current State:

Urban Qualification:

C. Cruz

Aggregate

$2018.27 \mathrm{~m} 2$

Private

8

18

Partially occupied

(US) Urban Soil

Solar D

Location: C. N. Sra. de las Nieves, C. Montorne

Type:

Through

Total surface area:

$534.69 \mathrm{~m} 2$

Property:

Private

Parcels number: 2

Sub-parcels number: 4

Current State: Car park

Urban Qualification: (US) Urban Soil

In all four cases analyzed, the surface of an entire solar, administratively, has more than one cadastral reference. This very often is one of the impediments to the rebuilding, since it is virtually impossible to build a property of any kind, on an area, often of a few square meters, divided among multiple owners. It is therefore necessary to gather them to reach the minimum required area of law, which in the case of Carmen (the neighborhood where the presence of the Solares is the largest) is 100 square meters with a street front of at least 6 ml. (Art. 50 PEPRI Carmen). However, it is granted to owners of buildings legally declared abandoned, to demolish and to reconstruct them, although the minimum requirements of the law are not met. In these specific cases, the holder of the property is required to apply for a building permit within two years. After this deadline, the property will be registered with the RMSER (Municipal Register of Solares and Buildings in Rehabilitation). The latter is where ownership of each property passes forcibly to the administration, which decides to entrust it to anyone presenting a project when the owner does not demonstrate the ability, or simply the will, to make other use. Also the owner 
of Solares, if he did not express intention to build in the short term, can ask spontaneously to be registered to RMSER having access to a possible compensation or owned shares of the new building constructed. The RMSER is thus the only tool available to the Public Administration to encourage the owners to rebuild, utilizing the eventual expropriation of the property or in the event of excessive parcelling, to consort and create a spontaneous urban regeneration intervention. If from a historical point of view the origins of these urban spaces are easily found, it is therefore in the legislative and economic spheres that lay the reasons why those voids have not been the subject of attention and speculation on the part of the owners, whether public or private.

From a legislative point of view:

There is a legal order in Spain concerning urban regulations, very complex and articulated on multiple levels of intervention ranging from the most general, national, to the individual intervention plans of the specific district. The main laws concerning the protection and preservation of cultural and architectural heritage at national level are: Law 16/1985 and Law 04/1998, which are developed and articulated in various local town-planning regulations. In the case of Valencia, reference is made to the ROGTU (Ordinance of Ordinance and Urban and Territorial Management) and goes even further into the PGOU (General Plan of Urban Ordination) that regulates the city's urban activity. In our specific case, having contained the field of analysis at Ciudad Vella, the PEPRI (Special Plans for Internal Reform Protection) provide us with the guidelines for the planning and design of any intervention, whether it be restructuring or conservation, falling within the Perimeter of the historic city. "Los solares deberán ser mantenidos limpios de vegetación y restos de inmundicias, vallados con cerramiento permanente de dos cincuenta metros de altura, de adecuada presencia, consistencia y resistencia, cercando la alineación oficial. Deberá propiciarse el adecuado tratamiento de la superficie del solar para evitar el riesgo de accidentes." (Art.3.58.1.d de las N.U. del PGOU).

From an economic point of view:

The word "void" expresses the potential of a container, apparently without content, waiting to be filled with new buildings or new activities. This urban void is the subject of a major economic interest: their use promises both savings with respect to the cost of abandonment, which would result in loss of property and maintenance. To better understand the underlying causes of the phenomenon (why the Solares are often abandoned) a brief market investigation has been conducted in order to know the price and to monitor the trading transitions. By simplifying, here are twelve selling cases:

\begin{tabular}{|c|c|c|c|c|c|c|}
\hline & Ref. & $\mathbf{m}^{\mathbf{2}}$ & Location & $\boldsymbol{\epsilon}$ & Building area & $\boldsymbol{\epsilon} / \mathbf{m}^{\mathbf{2}}$ \\
\hline 1 & 5827 & 61 & El Mercat & 270.000 & 240 & 4.426 \\
\hline 2 & E009-02125 & 418 & Torres de Quart & 1.150 .000 & 1.739 & 2.751 \\
\hline 3 & $0077-290532$ & 488 & Carmen & 1.150 .000 & 2.223 & 2.357 \\
\hline 4 & SU-105 & 450 & Ciutat Vella & 1.000 .000 & 1.100 & 2.222 \\
\hline 5 & $46-340-27$ & 103 & Carmen & 330.000 & 300 & 3.204 \\
\hline 6 & VAL-5850 & 500 & De La Seu & 1.200 .000 & 1.100 & 2.400 \\
\hline 7 & 378 & 340 & Carmen & 950.000 & 753 & 2.794 \\
\hline 8 & Bolseria & 61 & El Mercat & 260.000 & 240 & 4.262 \\
\hline 9 & Quart & 75 & Carmen & 315.000 & 300 & 4.200 \\
\hline 10 & Eixarchs & 55 & El Mercat & 250.000 & 320 & 4.545 \\
\hline 11 & Carme & 103 & Carmen & 330.000 & 412 & 3.203 \\
\hline 12 & Xerea & 350 & La Xerea & 990.000 & 990 & 2.828 \\
\hline Average & & $\mathbf{2 5 0}$ & & $\mathbf{6 8 2 . 9 1 7}$ & & $\mathbf{3 . 2 6 6}$ \\
\hline
\end{tabular}


The survey above shows how the average price of solares taken in the sample is about $3,000 € / \mathrm{m} 2$, with a surface of $250 \mathrm{~m} 2$. This data shift the focus of the problem to the permanence of the latters on the legislative sphere, because, as a building plot in the heart of the historical center, the average market prices turn out to be quite accessible. If we also think of the new, high tourist flows that are now affecting the city of Valencia and the consequent growth of accommodation facilities, we might hope for the natural disappearance of the above mentioned voids if there were no major problems from the administrative point of view.

From an environmental point of view:

Are the solares an environmental problem? From a strictly energy-performative point of view we could argue no. Being "non-places", their more or less virtuous behaviour does not constitute in itself a problem. But as an integral part of a compact fabric such as that of the historic center of Valencia they are a serious problem, even from an environmental point of view. These are places of great environmental concern: excessive shadowing in winter seasons, excess sunshine in summer, Heat Island phenomenon generated by the non-permeable and highly degraded materials that often constitute them, excessive (Canyon effect) or insufficient ventilation and so on. Basically they are places characterized by a strong environmental dis-comfort which makes them unsuitable for urban living.

For this reason an environmental analysis of the solar (case by case) was necessary. Any intervention on the urban voids can not, in fact, be without solving its outdoor comfort conditions. The validation protocol adopted for Valencia has thus provided a reading of the state of facts through some fundamental climatic conditions such as temperature, humidity, rainfall, wind, solar radiation. These were added to the following: findings on the site morphology and the shape and porosity factors of the isolates, light analysis in relation to the altimetric profile of the involved sections and their albedo values, tracing of the solar axonometries on particular days considered "threshold period", from dawn to sunset, from which to obtain the map of shading of the whole solar year.

The phases of the analysis protocol can be summarized as follows:

- Analysis of urban morphology (heights and densities of the isolates)

- Analysis of luminous contributions and distribution of albedo values through the use of solar axonometries and three-dimensional diagrams of the isolate

- Climate and microclimate analysis of the area (medium temperature and wind profiles)

- Analysis of irradiation profiles and solar axonometries.

More precisely, we can talk about microclimate analysis that can be carried out through the effective survey of each void regarding:

- Analysis of thermal comfort,

- Analysis of radiant components

- Wind component analysis

- Visual comfort analysis.

In order to carry out this kind of investigation, specific climatic software has been used to obtain data such as: average temperatures, relative humidity, precipitation percentage, mean values and peak values on irradiation. These data led to the elaboration of solar mapping and shading paths and other thematic maps to determine which areas were most affected by direct sunlight, such as those affected by more shadow hours during the summer and winter seasons.

Similarly, the wind component analysis was performed by comparing the following parameters:

- Dimension of outdoor space

- Wind speed at $2 \mathrm{~m}$ high

- Height adjacent buildings

- Direction of the wind, amplitude and location of the open faces of urban solares-urban canyon.

Environmental data are thus some of the necessary tools (along with normative, economic and morphological) to solve the solar problem as a major urban theme.

From a morphological point of view:

The different localization of solares within the historical fabric is perhaps the best way 
to analyze the transformative potential of these voids. If, on the one hand, size, number of faces, soil regime, urban and regulatory requirements are necessary tools for any intervention within the single solares, on the other hand, they are not sufficient to assess the type of intervention that is desirable. It is only the different types of paths on which every single void insists on suggesting, with good approximation, the function (residential, commercial, services, tertiary, etc.) attributable to them, the form and the choice of how to build (if wholly or partially) the solar. It is, in other words, the degree and the level of nodality of each void to indicate its potential function, it is the morphology of the tissue, together with the environmental analysis (conducted on a case-by-case) to suggest the new building form, it is the union of these two elements to define, in the final analysis, the new tissue: the new open spaces (public/private), new paths, heights of buildings etc. Thus, for example, a solar insisting on a Matrix path or a solar linking two Matrix paths or a Matrix path and a Building path will be likely to assume a special non-residential function. If then it is equipped with a sufficient size to allow it, it will in turn be able to accommodate a connection path between two roads. If the shape of the fabric so requires, it may involve the presence of a public (squares) or private space (courts, gardens) to be alternated in the construction and so on. All this, together with specific (regulatory and urban) constraints, allows to develop possible alternative intervention strategies. Strategies that are sufficiently dynamic to adapt to individual case studies but at the same time methodologically coordinated, so as to offer a credible and enforceable solution to the solares problem in the historic center of Valencia and, we believe, of any other historical city that can be assimilated to it.

\section{Conclusion}

A multidisciplinary approach to the study and project of the city is now needful, especially when it comes to dealing with issues relating to soil consumption, density, compactness and stratification of the historic city. The case of the solares of the historic center of Valencia was thus the starting point for developing a strategic intervention format in which the urban morphology acted as a scientific base to different disciplines. Thus, it was possible to define a first Due Diligence of urban voids where urban planning requirements, regulatory constraints, socio-economic data, and environmental analysis could be transformed into elements of the same puzzle able to define the context conditions characterizing the urban solares topic. Each of them, obviously, has features of its own that require a specific solution, but within a general format capable of solving the problem of solares on an urban scale, capable in other words of seizing the potentialities (not only the critical aspects) of a phenomenon that for the time dimension and diffusion into the fabric now plays a central role in the redevelopment and regeneration of the city of Valencia.

\section{References}

Gherri, B. (2016) 'Environmental Analysis Towards Low Carbon Urban Retrofitting For Public Spaces', 5th International Conference on Heritage and Sustainable Development 1, 499-508.

Gherri B. (2015) Assessment of Daylight Performance in Buildings: Methods and Design Strategies (WIT Press, Boston).

Gherri, B. (2016) 'Environmental Assessment method for Decarbonised Urban renewal', NewDist: SBE16 Towards Post-Carbon Cities, vol. 2, p. 114-122.

Guarini, M.R. Buccarini C., Battisti F., (2015)'Valutazione della fattibilità tecnica economica di un intervento di recupero edilizio', Estimo: temi e questioni contemporanee, (Politecnico di Bari, Bari).

Maretto, M. (2015) 'Polarities, Paths, Fabrics. The role of urban morphology in contemporary Urban Design', U+D urban form and design 03/04, 46-65.

Maretto, M. (2014) 'Sustainable Urbanism: the role of urban morphology', Urban Morphology 18(2), 163-74.

Maretto, M. (2012b) Ecocities. Il progetto urbano tra morfologia e sostenibilità (Franco 
Angeli, Rome-Milan).

Maretto, M. (2008) Il Paesaggio delle

differenze (ETS Edizioni, Pisa).

\section{Appendix}

\begin{tabular}{|c|c|c|c|c|c|}
\hline Parcel & $\begin{array}{c}\text { Parcel } \\
\text { Number }\end{array}$ & $\begin{array}{c}\text { Total surface } \\
\text { area }\left(\mathbf{m}^{2}\right)\end{array}$ & & $\begin{array}{l}\text { o-parcels } \\
\text { ea }\left(m^{2}\right)\end{array}$ & Cadastral Ref. \\
\hline \multirow{3}{*}{ A1 } & \multirow{3}{*}{3} & \multirow{3}{*}{210.59} & 1 & 176.27 & \multirow{3}{*}{5429813} \\
\hline & & & 2 & 3.58 & \\
\hline & & & 3 & 30.74 & \\
\hline \multirow[t]{2}{*}{ A2 } & \multirow[t]{2}{*}{2} & \multirow[t]{2}{*}{46.67} & 1 & 26.45 & \multirow[t]{2}{*}{5429807} \\
\hline & & & 2 & 20.23 & \\
\hline \multirow[t]{2}{*}{ A3 } & \multirow[t]{2}{*}{2} & \multirow[t]{2}{*}{213.32} & 1 & 54.24 & \multirow[t]{2}{*}{5429808} \\
\hline & & & 2 & 159.08 & \\
\hline \multirow[t]{3}{*}{ A4 } & \multirow[t]{3}{*}{3} & \multirow[t]{3}{*}{85.03} & 1 & 25.00 & \multirow{3}{*}{5429809} \\
\hline & & & 2 & 41.21 & \\
\hline & & & 3 & 18.82 & \\
\hline \multirow[t]{2}{*}{ A5 } & \multirow[t]{2}{*}{2} & \multirow[t]{2}{*}{60.57} & 1 & 40.50 & \multirow[t]{2}{*}{5429812} \\
\hline & & & 2 & 20.07 & \\
\hline \multirow[t]{2}{*}{ A6 } & \multirow[t]{2}{*}{2} & \multirow[t]{2}{*}{75.09} & 1 & 49.66 & \multirow[t]{2}{*}{5429811} \\
\hline & & & 2 & 25.43 & \\
\hline \multirow[t]{2}{*}{ A7 } & \multirow[t]{2}{*}{2} & \multirow[t]{2}{*}{135.67} & 1 & 43.83 & \multirow[t]{2}{*}{5429810} \\
\hline & & & 2 & 91.83 & \\
\hline 7 & 16 & 826.94 & & & \\
\hline
\end{tabular}

\begin{tabular}{c|c|c|c|c|c|c|}
\hline Parcel & $\begin{array}{c}\text { Parcel } \\
\text { Number }\end{array}$ & $\begin{array}{c}\text { Total surface } \\
\mathbf{a r e a}\left(\mathbf{m}^{2}\right)\end{array}$ & \multicolumn{2}{|c|}{$\begin{array}{c}\text { Sub-parcels } \\
\text { area }\left(\mathbf{m}^{2}\right)\end{array}$} & Cadastral Ref. \\
\hline B1 & 1 & 32.48 & \multicolumn{2}{|c|}{32.48} & 5729503 \\
\hline B2 & 1 & 37.60 & \multicolumn{2}{|c|}{37.60} & 5729504 \\
\hline B3 & 2 & 213.32 & 1 & 53.91 & 5429808 \\
\cline { 4 - 5 } & & & 2 & 5.97 & \\
\hline B4 & 2 & 85.03 & 1 & 20.26 & \multirow{2}{*}{5729506} \\
\cline { 1 - 4 } & & & 2 & 10.15 & \\
\hline
\end{tabular}

Figure 1a.

List of Solares. A and B 


\begin{tabular}{|c|c|c|c|c|}
\hline Parcel & $\begin{array}{c}\text { Total surface } \\
\text { area }\left(\mathbf{m}^{2}\right)\end{array}$ & \multicolumn{2}{|c|}{$\begin{array}{c}\text { Sub-parcels } \\
\text { area }\left(\mathbf{m}^{2}\right)\end{array}$} & $\begin{array}{c}\text { Cadastral } \\
\text { Ref. }\end{array}$ \\
\hline \multirow[t]{2}{*}{$\mathrm{C} 1$} & \multirow[t]{2}{*}{429.98} & 1 & 203.66 & \multirow[t]{2}{*}{5633917} \\
\hline & & 2 & 226.32 & \\
\hline \multirow[t]{3}{*}{$\mathrm{C} 2$} & \multirow[t]{3}{*}{773.49} & 1 & 550.44 & \multirow[t]{3}{*}{5633908} \\
\hline & & 2 & 189.06 & \\
\hline & & 3 & 33.99 & \\
\hline \multirow[t]{2}{*}{$\mathrm{C} 3$} & \multirow[t]{2}{*}{163.21} & 1 & 127.05 & \multirow[t]{2}{*}{563320} \\
\hline & & 2 & 36.16 & \\
\hline \multirow[t]{2}{*}{$\mathrm{C} 4$} & \multirow[t]{2}{*}{153.78} & 1 & 119.41 & \multirow[t]{2}{*}{5633921} \\
\hline & & 2 & 34.37 & \\
\hline \multirow[t]{2}{*}{$\mathrm{C} 5$} & \multirow[t]{2}{*}{10.11} & 1 & 15.08 & \multirow[t]{2}{*}{5633903} \\
\hline & & 2 & 94.02 & \\
\hline \multirow[t]{3}{*}{ C6 } & \multirow[t]{3}{*}{92.17} & 1 & 1.45 & \multirow[t]{3}{*}{5633904} \\
\hline & & 2 & 78.05 & \\
\hline & & 3 & 12.68 & \\
\hline \multirow[t]{2}{*}{$\mathrm{C} 7$} & \multirow[t]{2}{*}{112.98} & 1 & 83.10 & \multirow[t]{2}{*}{5633905} \\
\hline & & 2 & 39.88 & \\
\hline \multirow[t]{2}{*}{$\mathrm{C} 8$} & \multirow[t]{2}{*}{183.65} & 1 & 35.78 & \multirow[t]{2}{*}{5632305} \\
\hline & & 2 & 147.87 & \\
\hline 8 & 2018.27 & & & \\
\hline
\end{tabular}

\begin{tabular}{|c|c|c|c|c|c|c|}
\hline \multirow{3}{*}{\multicolumn{2}{|c|}{\begin{tabular}{|c|} 
Parcel \\
D1
\end{tabular}}} & \multirow{3}{*}{$\begin{array}{c}\begin{array}{c}\text { Parcel } \\
\text { Number }\end{array} \\
2\end{array}$} & \multirow{3}{*}{$\begin{array}{c}\begin{array}{c}\text { Total surface } \\
\text { area }\left(\mathbf{m}^{\mathbf{2}}\right)\end{array} \\
122.84\end{array}$} & \multicolumn{2}{|c|}{$\begin{array}{l}\text { Sub-parcels } \\
\text { area }\left(\mathbf{m}^{2}\right)\end{array}$} & \multirow{3}{*}{$\begin{array}{c}\begin{array}{c}\text { Cadastral } \\
\text { Ref. }\end{array} \\
6228107\end{array}$} \\
\hline & & & & 1 & 117.67 & \\
\hline & & & & 2 & 5.17 & \\
\hline & \multirow[t]{2}{*}{ D2 } & \multirow[t]{2}{*}{2} & \multirow[t]{2}{*}{411.85} & 1 & 397.29 & \multirow[t]{2}{*}{6228106} \\
\hline & & & & 2 & 14.56 & \\
\hline TOT. & 2 & 4 & 534.69 & & & \\
\hline
\end{tabular}

Figure 1b.

List of Solares. C and D 